\title{
Pengaruh Perkawinan Usia Muda Terhadap Pola Asuh Keluarga Di Kota Baubau
}

\author{
Wa Ode Wati Nurbaena \\ Pegawai Badan Kependudukan dan Keluarga Berencana Kota Baubau \\ Telp. +6281245733774
}

\begin{abstract}
Abstrak, Tujuan penelitian ini menaruh pokok kajian pada dinamika perkawinan usia muda dan implikasi yang sering menjadi keluhan dan masalah yang ditemui beberapa tahun ini. Disisi lain, kajian ini juga menaruh perhatian lebih pada peran dari pemerintah daerah dalam memberikan pengawasan dan pembinaan pada kejadian pernikahan usia muda khususnya di Kota Baubau. Penelitian menggunakan metode kualitatif dengan pendekatan deskriptif. Hal ini menjadi alasan untuk menggunakan metode kualitatif adalah sejalan dengan tujuan penelitian ini yang ingin mendapatkan data deskriptif berupa lisan atau kata-kata dari gejala yang diamati atau diteliti. Berdasarkan hasil penelitian di atas, mengenai faktor-faktor pendorong, dampakdampak dan bentuk pola asuh keluarga dalam pasangan yang menikah pada usia muda, dipengaruhi oleh adanya tekanan pada beberapa faktor diantaranya adalah faktor ekonomi, faktor orang tua, faktor pendidikan, faktor diri sendiri dan faktor adat setempat.
\end{abstract}

\section{Kata Kunci: Perkawinan Usia Muda}

Abstract, The purpose of this study is to put the subject of a study on the dynamics of young age marriage and the implications that are often the complaints and problems encountered in recent years. On the other hand, this study also paid more attention to the role of the local government in providing supervision and guidance to the incidence of young marriages, especially in Baubau. The study used qualitative methods with a descriptive approach. This is the reason for using qualitative methods that are in line with the purpose of this study who want to get descriptive data in the form of oral or words of symptoms observed or examined. Based on the results of the above research, regarding the driving factors, impacts and forms of family care in couples who marry at a young age, are influenced by the pressure on several factors including economic factors, parent factors, educational factors, self-factors and local custom factors.

Keywords: Young Age Marriage 


\section{Pendahuluan}

Salah

satu

masalah

kependudukan saat ini adalah maraknya pernikahan usia muda, namun tidak diikuti dengan persiapan mental yang memadai. Akibatnya terjadi fenomena meningkatnya kasus perceraian karena kurangnya kesadaran untuk bertanggung jawab dalam kehidupan berumah tangga bagi suami istri. Pernikahan yang sukses sering ditandai dengan kesiapan memikul tanggungjawab. Begitu memutuskan untuk menikah, mereka siap menanggung segala beban yang timbul akibat adanya pernikahan, baik yang menyangkut pemberian nafkah, pendidikan anak, maupun yang berkait dengan perlindungan, pendidikan, serta pergaulan yang baik. Tujuan dari perkawinan yang lain adalah memperoleh keturunan yang baik. Dengan perkawinan pada usia yang terlalu muda mustahil akan memperoleh keturunan yang berkualitas. Kedewasaan ibu juga sangat berpengaruh terhadap perkembangan anak, karena ibu yang telah dewasa secara psikologis akan akan lebih terkendali emosi maupun tindakannya, bila dibandingkan dengan para ibu muda. Selain mempengaruhi aspek fisik, umur ibu juga mempengaruhi aspek psikologi anak, ibu usia remaja sebenarnya belum siap untuk menjadi ibu dalam arti keterampilan mengasuh anaknya. Ibu muda ini lebih menonjolkan sifat keremajaannya daripada sifat keibuannya.

\section{Dalam literature yang} menjelaskan remaja secara psikologis, Zakiyah Daradjat (1975) mendefinisikan remaja sebagai anak yang ada pada masa peralihan dari masa anak-anak menuju usia dewasa pada masa peralihan ini biasanya terjadi percepatan pertumbuhan dalam segi fisik maupun psikis. Baik ditinjau dari bentuk badan, sikap, cara berpikir dan bertindak mereka bukan lagi anak-anak. Mereka juga belum dikatakan manusia dewasa yang yang memiliki kematangan pikiran.

Perkawinan usia muda juga membawa pengaruh yang tidak baik bagi anak-anak mereka. Biasanya anakanak kurang kecerdasannya. Sebagaimana dikemukakan oleh Ancok (2003) menjelaskan bahwa Anak-anak yang dilahirkan oleh ibu-ibu remaja mempunyai tingkat kecerdasan yang lebih rendah bila dibandingkan dengan anak yang dilahirkan oleh ibu-ibu yang lebih dewasa. Rendahnya angka kecerdasan anak-anak tersebut karena si ibu belum memberi stimulasi mental 
pada anak-anak mereka. Hal ini disebabkan karena ibu-ibu yang masih remaja belum mempunyai kesiapan untuk menjadi ibu.

Peranan orang tua sangat besar artinya bagi perkembangan psikologis anak-anaknya.orang tua dengan anak akan mempengaruhi kepribadian anaknya dimasa dewasanya. Anak yang masih dalam proses perkembangan tersebut mempunyai kebutuhankebutuhan pokok terutama kebutuhan rasa aman, sayang dan kebutuhan rasa harga diri. Apabila kebutuhankabutuhan tersebut tidak terpenuhi akan mengakibatkan goncangan pada perkembangan anak Masih banyak orang tua yang belum menyadari pentingnya keterlibatan mereka secara langsung dalam mengasuh anak. Tak jarang akibatnya merugikan perkembangan fisik dan mental anaknya sendiri.

Pada umumnya wanita yang telah melangsungkan perkawinan di usia muda di Kota Baubau tidak semua memiliki tingkat kedewasaan/kematangan yang ideal yang sesuai dengan pasal 7 ayat (1) UU No 1 tahun 74. Mengingat keluarga adalah tempat pertama bagi tumbuh kembangnya anak sejak lahir hingga dewasa maka pola asuh anak dalam keluarga perlu disebarluaskan pada setiap keluarga. Kepada pasangan usia muda tersebut seharusnya diberikan pembekalan yang memadai tentang norma-norma berkeluarga, adat istiadat, perilaku dan budaya malu serta rasa hormat, pemahaman agama. Masih banyak orang tua yang belum menyadari pentingnya keterlibatan mereka secara langsung dalam mengasuh anak. Tak jarang akibatnya merugikan perkembangan fisik dan mental anaknya sendiri.

Penyebab terjadinya perkawinan di usia muda ini dipengaruhi oleh berbagai macam faktor. Rendahnya tingkat pendidikan mereka sangat mempengaruhi pola pikir mereka dalam memahami dan mengerti tentang hakekat dan tujuan perkawinan. Faktor ekonomi maupun lingkungan tempat mereka tinggal juga bisa menjadi penyebab terjadinya perkawinan di usia muda.

Menurut Soerojo wignjodipuro (1994) bahwa perkawinan anak-anak biasanya terjadi karena untuk sekedar memenuhi kebutuhan/kekurangan pembiayaan hidup orang tuanya, khususnya orang tua mempelai wanita, sebab dengan menyelenggarakan perkawinan anak-anak ini akan diterima sumbangan berupa barang, bahan 
ataupun sejumlah barang dari handai taulannya yang dapat di pergunakan selanjutnya untuk menutupi kebutuhan biaya kehidupan sehari-hari, untuk beberapa waktu lamanya.

Fenomena yang terjadi di Indonesia hingga akhir tahun 2017, pernikahan dini berkisar 12-20\% yang dilakukan oleh pasangan baru. Biasanya, pernikahan dini dilakukan pada pasangan usia muda usia rata-rata umurnya antara 16-20 tahun. Secara nasional pernikahan dini dengan usia pengantin di bawah usia 16 tahun sebanyak 26,95\%. Padahal pernikahan yang ideal untuk perempuan adalah 2125 tahun sementara laki-laki 25-28 tahun. Karena di usia itu organ reproduksi perempuan secara psikologis sudah berkembang dengan baik dan kuat serta siap untuk melahirkan keturunan secara fisik pun mulai matang. Sementara laki-laki pada usia itu kondisi psikis dan fisiknya sangat kuat, hingga mampu menopang kehidupan keluarga untuk melindungi baik sera psikis emosional, ekonomi dan sosial.

Dampak dari perkawinan usia muda akan menimbulkan persoalan dalam rumah tangga, seperti pertengkaran, percekcokan bentrokan antara suami-istri. Emosi yang belum stabil, memungkinkan banyaknya pertengkaran dalam berumah-tangga. Di dalam rumah tangga pertengkaran atau bentrokan itu hal biasa, namun apabila berkelanjutan akan mengakibatkan suatu perceraian.

Berdasarkan pada fenomena diatas, penelitian ini menaruh pokok kajian pada dinamika perkawinan usia muda dan implikasi yang sering menjadi keluhan dan masalah yang ditemui beberapa tahun ini. Disisi lain, kajian ini juga menaruh perhatian lebih pada peran dari pemerintah daerah dalam memberikan pengawasan dan pembinaan pada kejadian pernikahan usia muda khususnya di Kota Baubau.

\section{Metode Penelitian}

Penelitian menggunakan metode kualitatif dengan pendekatan deskriptif. Hal ini menjadi alasan untuk menggunakan metode kualitatif adalah sejalan dengan tujuan penelitian ini yang ingin mendapatkan data deskriptif berupa lisan atau kata-kata dari gejala yang diamati atau diteliti. Menurut Kirt dan Miller mendefinisikan bahwa penelitian kualitatif adalah tradisi tertentu dalam ilmu pengetahuan sosial yang secara fundamental tergantung pada pengamatan terhadap manusia dalam kawasannya sendiri dan 
berhubungan dengan orang-orang tersebut dalam bahasannya dan dalam peristilahannya (Rachman, 1999:118).

\section{Hasil Penelitian dan Pembahasan}

1. Faktor Pendorong Perkawinan Usia Muda

Dalam sejumlah observasi dan wawancara penelitian yang dilakukan, alasan adanya pernikahan usia dini dapat diklasifikasikan menurut beberapa faktor, yaitu sebagai berikut:

\section{a. Tekanan Ekonomi}

Adanya perkawinan usia muda di Kota Baubau sebagian besar disebabkan kerena kondisi ekonomi keluarga yang kurang. Para orang tua yang menikahkan anaknya pada usia muda mengganggap bahwa dengan menikahkan anaknya beban ekonomi keluarga akan berkurang satu. Hal ini disebabkan karena jika anak sudah menikah, maka akan menjadi tanggung jawab suaminya. Bahkan para orang tua berharap jika anaknya sudah menikah dapat membantu kehidupan orang tuanya.

\section{b. Motivasi Sendiri}

Yang dikatakan oleh Muksin dan Ida mereka melangsungkan perkawinan usia muda bukan kehendak orang tua ataupun faktor ekonomi yang kurang mencukupi, melainkan karena kemauannya sendiri.
Hal ini juga disampaikan oleh Endan (25) yang menikah pada usia 19 tahun dengan Dede Nurhasanah (20) tahun menikah pada usia 16 tahun, dalam wawancara yang dilakukan informan penelitian mengemukakan bahwa :

"Kami melangsungkan perkawinan pada usia muda dikarenakan kami sudah lama saling mencintai dan kami takut apabila kami berbuat halhal yang tidak diinginkan.

Kerena ia sangat mencintai kekasihnya, maka la memutuskan untuk mempercepat pernikahan. salah satu faktor adalah karena la takut terjadi halhal yang memalukan keluarganya, sehingga merekapun memilih untuk menikah dalam usia yang masih muda.

Dari pendapat-pendapat di atas, maka dapat disimpulkan bahwa perkawinan usia muda selain karena keadaan ekonomi orang tua yang tidak mencukupi, juga karena kehendak dan kemauan sendiri.

\section{c. Tingkat Pendidikan}

Rendahnya pendidikan juga merupakan faktor terjadinya pernikahan usia muda. Tingkat pendidikan orang tua informan penelitian yang rata-rata adalah tamatan SD/ Sederajat, menjadikan pertimbangan adat adalah paling utama. Dengan begitu, mereka menganggap 
bahwa menikahkan anaknya secepat mungkin tanpa memerhatikan kesiapan usia, mental dan sejumlah faktor lainnya cenderung sangat abai dengan hal itu.

\section{d. Persetujuan Orang Tua}

Faktor orang tua merupakan faktor adanya perkawinan usia muda, dimana orang tua akan segera menikahkan anaknya jika sudah menginjak besar. Hal ini merupakan hal yang sudah biasa atau turun-temurun.

Pengaruh yang paling sering ditemu dari fenomena menikah muda adalah adanya perasaan khawatir orang tua terhadap anaknya melakukan perbuatan yang dapat merusak nama baik keluarganya, pertimbangan ini kemudian menjadikan orang tua memberikan restu pernikahan anaknya sekalipun anaknya masih dalam usia muda.

Sebagian besar pasangan menikah muda disebabkan adanya kurangnya pengetahuan yang dimiliki oleh orang tua yang melangsungkan perkawinan muda di Kota Baubau terhadap perkawinan. Mereka tidak begitu memikirkan bagaimanakah keadaan anaknya setelah berumah tangga yang penting bagi mereka anaknya sudah menikah dan sudah ada yang mau menanggung kebutuhan anak perempuannya serta orang tua berharap dari perkawinan yang telah dilangsungkannya itu anaknya itu dapat membantu kebutuhan orang tuanya.

Dari penjelasan diatas dapat disimpulkan dalam table 1 .

Tabel 1

Persentase Faktor-faktor Pendorong Perkawinan Usia Muda

\begin{tabular}{|c|c|c|}
\hline $\begin{array}{c}\text { Faktor Yang } \\
\text { Memengaruhi }\end{array}$ & $\begin{array}{c}\text { Jumlah } \\
\text { Pasangan }\end{array}$ & $\%$ \\
\hline Faktor ekonomi & 3 & 47,5 \\
\hline Faktor orang tua & 2 & 25 \\
\hline Faktor pendidikan & 1 & 12,5 \\
\hline Faktor diri sendiri & 1 & 12,5 \\
\hline Faktor adat Setempat & 1 & 12,5 \\
\hline Total & 8 & 100 \\
\hline
\end{tabular}

Sumber : Olah Data Penelitian

\section{Pembahasan}

Perkawinan merupakan suatu ikatan yang menunjukkan hubungan antara pribadi dengan pribadi lain. Sebuah ikatan perkawinan terjadi karena adanya kecocokan pribadi, psikologi, rasio dan fisik antara.Oleh sebab itu, hubungan pernikahan ini merupakan upaya penyatuan antar pribadi dan antar individu yang jelas berbeda tabiatnya.

Dalam pasal 7 ayat 1 Tahun 1974 telah ditetapkan bahwa: Perkawinan hanya diijinkan jika pihak pria sudah mencapai umur 19 tahun dan pihak wanita sudah mencapai umur 16 tahun. Namun dalam prateknya masih banyak 
kita jumpai perkawinan pada usia muda atau di bawah umur.

Pasal 6 ayat 2 UU No 1 Tahun 1974 menyatakan bahwa untuk melangsungkan perkawinan seorang yang belum mencapai umur 21 tahun harus mendapat izin dari kedua orangtua. Biasanya pernikahan dini dilakukan oleh pasangan usia muda yang usianya rata-rata umur antara 1620 tahun.

Pernikahan dini merupakan sebuah perkawinan di bawah umur yang target persiapannya belum dikatakan maksimal meliputi persiapan fisik, mental, juga persiapan materi. Ketiga persiapan inilah yang seharusnya dijadikan sebagai persyaratan seseorang jika ia sudah mau mengakhiri masa lajangnya dan masuk pada masa keluarga.

$\begin{array}{ccc}\text { Setiap } & \text { manusia } & \text { yang } \\ \text { melangsungkan } & \text { perkawinan } & \text { untuk } \\ \text { membangun rumah tangga } & \text { pasti }\end{array}$
semuanya dengan harapan untuk dapat memperoleh kebahagiaan baik bagi dirinya maupun bagi orang-orang sekitarnya khususnya keluarganya sendiri. Untuk dapat mencapai kebahagiaan tersebut yang sesuai dengan tujuan perkawinan yaitu membentuk rumah tangga yang bahagia dan kekal berdasarkan Ketuhanan Yang
Maha Esa, yang tidak hanya melihat dari segi lahiriah saja tetapi sekaligus terdapat adanya suatu pertautan batin antara suami istri yang ditujukan untuk membina bahtera rumah tangga yang kekal selamanya. Kurangnya pengetahuan masyarakat akan makna sebuah perkawinan akan mengakibatkan dampak yang kurang baik bagi berbagai pihak khususnya bagi pasangan itu sendiri juga akan meningkatkan jumlah angka perkawinan diusia muda itu sendiri.

Di Kota Baubau ada tidak jarang didapati orang tua yang menikahkan anaknya pada usia muda tanpa mempertimbangkan umur atau usia itu semua dilakukan karena keterbatasan pengetahuan orang tua terhadap makna perkawinan itu sendiri. Keluarga merupakan unsur yang sangat penting dalam kehidupan keluarga khususnya bagi anak-anak. Orangtua merupakan panutan bagi anaknya sekaligus sebagai guru yang sangat penting bagi perkembangan anak. Tentu saja setiap orangtua menginginkan anak-anaknya tumbuh dan berkembang secara normal. Orangtua sudah barang tentu memberikan anak-anaknya yang terbaik tetapi apa yang akan diterima oleh anak belumlah baik menurut mereka. 
Seperti halnya orangtuia selalu memberikan perhatian yang khusus pada anak perempuannya daripada anak laki-lakinya. Dalam halnya perkawinan orangtua selalu berusaha untuk mencarikan jodoh untuk anak perempuannya dengan syarat jodoh yang diberikannya itu sesuai dengan keinginan anaknya.

Bagi keluarga yang memiliki tingkat ekonomi yang kurang mereka akan segera menikahkan anaknya meskipun umur anaknya tersebut melum cukup untuk melangsungkan perkawinan. Mereka menikahkan anak perempuannya itu dikarenakan faktor ekonomi mereka. Dengan menikahkan anaknya pada usia muda maka mereka akan terlepas dari tanggung jawabnya untuk membiayai atau memenuhi kebutuhan hidupnya. Terjadinya perkawinan usia muda tidak hanya dikarenakan oleh faktor ekonomi saja, namun disamping itu orang tua juga menjadi faktor terjadinya perkawinan muda. Orang tua yang memiliki seorang anak perempuan akan merasa cemas apabila anaknya belum mempunyai pacar atau pendamping. Karena takut digunjingkan tetangganya maka orang tua akan ikut serta mencarikan jodoh untuk anaknya. Karena ditakutkan anaknya disebut perawan tua atau tidak laku maka orang tua akan segera menikahkan anak perempuannya itu pada orang yang datang ke rumah dan memintanya untuk dijadikannya seorang istri.

Pendidikan juga menjadi faktor terjadinya terjadinya perkawinan di bawah umur. Dengan keterbatasan pengetahuan yang dimiliki maka tidak menutup kemungkinan pola pikir mereka akan sempit. Di Kota Baubau kebanyakan dari mereka tidak dapat melanjutkan pendidikannya ke tingkat yang lebih tinggi, jadi pola pikir mereka ke masa yang akan datang pun kurang. Daripada anaknya hanya diam di rumah para orang tua lebih memilih untuk segera menikahkan anaknya.

Pendidikan merupakan hal yang penting dalam kehidupan manusia. Pemerintah telah mencanangkan wajib belajar 9 tahun yang telah ditetapkan, tetapi pada kenyataannya pendidikan tidak semuanya dapat dilaksanakan oleh penduduk Kta Baubau. Masih terdapat penduduk yang belum dapat menyekolahkan anak-anaknya ke jenjang yang lebih tinggi dikarenakan kurangnya biaya serta kesadaran orang tua terhadap pentingnya akan pendidikan.

$$
\text { Itulah faktor-faktor yang }
$$
mempengaruhi adanya perkawinan 
pada usia muda di Kota Baubau. Dampak dari perkawinan usia muda bagi pasangan suami istri pada umumnya adanya percekcokan kecil dalam rumahtangganya. Karena satu sama lainnya belum begitu memahami sifat keduanya maka perselisihan akan muncul kapan saja. Karena diantara keduanya belum bisa menyelami perasaan satu sama lain dengan sifat keegoisannya yang tinggi dan belum matangnya fisik maupun mental mereka dalam membina rumah tangga memungkinkan banyaknya pertengkaran atau bentrokan yang bisa mengakibatkan perceraian.

Emosi yang tidak stabil, memungkinkan banyaknya pertengkaran jika menikah di usia dini. Kedewasaan seseorang tidak dapat diukur dengan usia saja, banyak faktor seseorang mencapai taraf dewasa secara mental yaitu keluarga, pergaulan, IQ, dan pendidikan. Semakin dewasa seseorang semakin mampu mengimbangi emosionalitasnya dengan rasio. Mereka yang senang bertengkar cenderung masih kekanak-kanakan dan belum mampu mengekang emosi.

Gangguan kesehatan yang dialami oleh istri akan mempengaruhi juga pada kesehatan anak-anaknya, hal itu disebabkan karena umur ibu yang masih muda dan juga tingkat pendidikan mereka yang rendah sehingga pengetahuan yang ia miliki sangat minim. Kurangnya pengetahuan akan pentingnya hidup sehat, ekonomi yang lemah ditambah lagi kerepotan mengurus anak dapat juga menjadi penyebab responden tidak begitu memperhatikan kesehatannya.

Dampak terhadap masing-masing keluarga yaitu apabila perkawinan antara anak-anak mereka mengalami kegagalan akan menimbulkan persoalan yang serius yakni bisa terputusnya hubungan keluarga diantara keduanya yang kemudian akan mengakibatkan kesedihan bagi kedua belah pihak. Disamping itu apabila perceraian terjadi pada anak-anaknya maka orang tua turut dalam mendamaikan keduanya.

Dari pernyataan di atas kita dapat mengambil keputusan bahwa yang menikah pada usia muda sebelumnya mereka tidak begitu memikirkan dampak apa saja yang akan di timbulkan dari perkawinannya itu.

Selain rendahnya pemahaman masyarakat terhadap makna perkawinan, keadaan perekonomian masing-masing keluarga yang melangsungkan perkawinan pada usia muda rata-rata keadaan ekonominya lemah dan juga dikarenakan banyak sekali anak-anaknya yang tidak lagi 
melanjutkan sekolahnya kejenjang yang lebih tinggi.

Hasil temuan dilapangan bahwa pola asuh demokratis lebih mendorong anak jadi mandiri dan berprestasi dibandingkan dengan anak yang diasuh dengan cara otoriter. Hasil pola asuh pada pasangan muda ini untuk masingmasing pengasuhan anak adalah pola asuh demokratik, dan pola asuh penyabar atau pemanja.

Perbedaan pola asuh tersebut disebabkan oleh adanya faktor internal dan ekstrnal dari ibu-ibu muda tersebut. Pengasuhan yang dilakukan seseorang berkaitan pula dengan latar belakang pendidikan dari ibu muda tersebut.Pola asuh merupakan sikap orang tua dalam berhubungan dengan anaknya, sikap ini dapat dilihat dari berbagai segi, antara lain dari cara orang tua memberikan peraturan pada anak, cara memberikan hadiah dan hukuman, cara orang tua menunjukkan memberikan perhatian atau tanggapan terhadap keinginan anak. Dengan demikian yang disebut dengan pola asuh adalah bagaimana cara mendidik orang tua terhadap anak, baik secara langsung maupun tidak langsung.

Cara mendidik secara langsung artinya bentuk-bentuk asuhan orang tua yang berkaitan dengan pembentukan kepribadian, kecerdasan, dan keterampilan yang dilakukan secara sengaja baik berupa perintah, larangan, hukuman, penciptaan situasi maupun pemberian hadiah sebagai alat pendidikan. Dalam situasi seperti ini yang diharapkan muncul dari anak adalah efek-intruksional yaitu responrespon anak terhadap aktifitas pendidikan itu.

Pendidikan secara tidak langsung adalah berapa contoh kehidupan seharihari baik tutur kata sampai alat kebiasaan dan pola hidup, hubungan antara orang tua dengan keluarga, masyarakat, hubungan suami istri. Semua ini secara tidak sengaja telah membentuk situasi dimana anak selalu bercermin terhadap kehidupan seharihari.

Keluarga yang harmonis akan memberikan kemesraan pada hubungan orang tua-anak sehingga anak akan mempercayai orang tua. Anak akan timbul rasa kasih sayang terhadap orang tua dan anak akan tumbuh menjadi manusia dewasa yang demokratik. Begitu sebaliknya disebutkan pola bahwa orang tua yang tidak harmonis menyebabkan anak menjadi tidak percaya pada orang tua. Anak akan lari dari orang tua dan mencari kedamaian diluar rumahnya. Akibat dari itu maka 
anak merasa rendah diri, frustasi dan broken home.

Peranan orang tua sangat besar artinya bagi perkembangan psikologis anak-anak dimasa dewasanya. Anak yang masih dalam proses perkembangan tersebut mempunyai kebutuhan-kebutuhan pokok terutama kebutuhan rasa aman, sayang dan kebutuhan harga diri. Dari pernyataan di atas maka di Kota Baubau, para ibu rumahtangga yang menikah pada usia muda dalam pengasuhan anaknya lebih banyak menggunakan pola asuh demokratik.

Dengan pola asuh demokratif para orang tua tidak begitu mengekang pada anak-anaknya dan memaksakan kehendaknya pada anak-anaknya, sebaliknya mereka memberikan kepercayaan penuh terhadap anakanaknya untuk bisa menjalani kehidupannya dimasa yang akan datang.

\section{Kesimpulan}

Al-ghifari, Abu. 2004. Pernikahan Dini Dilema Generasi Ekstravagansa. Bandung: Mujahid.

Afandi, Ali, Prof, S.H. Hukum Waris Hukum Keluarga Hukum Pembuktian. Jakarta: PT. Rineka Cipta.

Arikunto, Suharsimi. 1996. Prosedur Penelitian Suatu Pendekatan Praktek. Jakarta: Rineka Cipta.
Berdasarkan hasil penelitian di atas, mengenai faktor-faktor pendorong, dampak-dampak dan bentuk pola asuh keluarga dalam pasangan yang menikah pada usia muda, dipengaruhi oleh adanya tekanan pada beberapa faktor diantaranya adalah faktor ekonomi, faktor orang tua, faktor pendidikan, faktor diri sendiri dan faktor adat setempat.

Sedangkan dampak yang timbul dari perkawinan usia muda meliputi: dampak pada suami istri yaitu terjadinya pertengkaran dan percekcokan kecil dalam rumahtangganya, dampak pada anak-anaknya yaitu rendahnya tingkat kecerdasan dan IQ pada anak serta adanya gangguangangguan pada perkembangan fisik anak.

\section{Daftar Pustaka}

Asmin, S.H. 1986. Status Perkawinan Antar Agama Tinjauan dari UU Perkawinan No 1 Tahun 1974. Jakarta: PT. Dian Rakyat.

Bimowalgito. 1993. Pengantar Psikologi Umum. Yogyakarta: Andi Ofset.

B.Ter Haar Bzn, Mr. 1960. Asas-asas dan Susunan Hukum Adat. Jakarta: Penerbit Pradnya Paramita. 
Danny. I. Yatin. 1986. Kepribadian keluarga dan Narkotika Jakarta : Ancan

Elizabeth, B.Hurlock,1994. Psikologi Perkembangan Suatu Pendekatan Sepanjang Rentang Kehidupan. Jakarta: Anggota IKAPI.

Hadikusuma, Hilman. 1983. Hukum Perkawinan Adat. Bandung : Alumni.

---------.. 1990. Hukum Perkawinan Indonesia. Bandung : Mandar Maju.

---------. 1992. Bahasa Hukum Indonesia. Alumni : Jakarta.

Martaniah, Mulyani. 1964. Peranan orang tua dalam perkembangan Kepribadian.

Milles, Mettew, B dan Hubberman, A. Michael. 1992. Analisis Data Kualitatif. Jakarta: Rosdakarya.

Fauzil Adhim, Mohammad. 2002. Indahnya Perkawinan Dini. Jakarta: Gema Insani.

Moleong, Lexy J. 2000. Metodologi Penelitian Kualitatif. Bandung: PT. Remaja Rosdakarya.
Nasruddin, Thoha. 1967. Pedoman Perkawinan Islam. Jakarta: Bulan Bintang.

Poerwadarminta, W.J.S. 1976. Kamus Umum Bahasa Indonesia. Yogyakarta: Universitas Gajah Mada.

Rachman, Maman. 1999. Strategi dan Langkah-langkah Penelitian. Semarang: IKIP Semarang Perss.

Soemiyati, S.H. Hukum Perkawinan Islam Dan Undnag-Undang Perkawinan. Yogyakarta: Liberty.

Soeryono, Soekanto. 1992. Sosiologi Suatu Pengantar. Jakarta:PT. Grafinda.

Subekti, Prof, S.H. 1993. Pokok-Pokok Hukum Perdata. Jakarta: PT. Intermasa.

Mangoenprasodjo, A. Setiono. 2004. Pengasuhan anak diera internet. Jogjakarta: Thinfresh.

Mohammad, M. Dlori. 2005. Jeratan nikah dini, wabah pergaulan. Jogjakarta : Media Abadi. 